\title{
THE ROLE OF APOPTOSIS, CELL PROLIFERATION INDEX, BCL-2, AND P53 IN GLIOBLASTOMA PROGNOSIS
}

\author{
Marlise de Castro Ribeiroㅁ, Lígia M. Barbosa Coutinho², Arlete Hilbig ${ }^{3}$
}

\begin{abstract}
Glioblastoma is the most common neuroectodermic tumor. It is also the most malignant one. Many genetic changes are found in glioblastomas, among them, the presence of oncoproteins $\mathrm{p5} 3$ and blc-2, as well as a high mitotic level and the presence of apoptosis. The utility of such findings through immunohistochemistry for the prognosis of patients remains uncertain. Our objectives in this study were to verify the presence of apoptosis, blc-2, p53, and the proliferative index (M IB-1), through immunohistochemistry, in 30 glioblastomas obtained by surgical resection between August 2000 and August 2001, as well as correlations between those immunohistochemical variables and the patient's age and survival time. Correlations between immunohistochemical variables themselves were also examined. For correlation calculations, Pearson's and Spermann's correlations were used and the time of survival was calculated with the Kaplan-M eier method. Results: No correlation was found between immunohistochemical variables and survival time. There was also no correlation between those variables and the patients' age. A moderate inverse correlation was found between the apoptotic index (AI) and the mitotic index (MI) $(p=0.058)$, besides an inverse correlation between blc-2 and MI. Conclusion: Our study has not demonstrated any of the examined immunohistochemical findings as having a predictive value in the prognosis of glioblastomas. A reverse correlation was found between $\mathrm{Al}$ and $\mathrm{MI}$, which has al ready been demonstrated by a few studies, as well as an inverse correlation between blc-2 and MI. This finding can demonstrate blc-2 as having a pro-apoptotic role in this group of tumors.
\end{abstract}

KEY WORDS: glioblastoma, apoptosis, p53, bcl-2, M IB-1, prognosis.

\begin{abstract}
0 papel da apoptose, do índice de proliferação celular, bcl-2 e p53 no prognóstico dos glioblastomas
RESUM 0 - 0 glioblastoma é o tumor neuroectodérmico mais comum e também o mais maligno. M uitas são as alterações genéticas encontradas nos glioblastomas, entre elas, a presença de oncoproteínas p53 e bcl-2, além de elevado índice mitótico e a presença de apoptose. A utilidade desses achados, através da imuno-histoquímica, no prognóstico dos pacientes ainda permanece incerta. Nossos objetivos neste estudo foram verificar a presença de apoptose, bcl-2, p53 e o índice proliferativo (M IB-1), através de imuno-histoquímica, em 30 glioblastomas obtidos através de ressecção cirúrgica entre agosto de 2000 e agosto de 2001 e também as correlações entre estas variáveis imuno-histoquímicas e a idade dos pacientes e o tempo de sobrevida. Também pesquisamos as correlações entre as variáveis imuno-histoquímicas entre si. Para os cálculos de correlação utilizamos Correlação de Pearson e Spearmann e a sobrevida foi calculada através do método de Kaplan-M eier. Resultados: Não houve correlação entre as variáveis imuno-histoquímicas e o tempo de sobrevida. Também não houve correlação entre estas variáveis e as idades dos pacientes. Encontramos correlação inversa de grau moderado entre o índice apoptótico (IA) e o índice mitótico (IM) $(p=0,058)$ e também correlação inversa entre bcl-2 e IM. Conclusão: Nosso estudo não demonstrou nenhum dos achados imuno-histoquímico pesquisado como tendo valor preditivo no prognóstico dos glioblastomas. Houve correlação inversa entre IA e IM, já demonstrada em alguns estudos e também correlação inversa entre bcl-2 e IM, achado que pode demonstrar um papel pró-apoptótico do bcl-2 neste grupo de tumores.
\end{abstract}

PALAVRAS-CHAVE: glioblastoma, apoptose, bcl-2, p53, MIB-1, prognóstico.

Fundação Faculdade Federal de Ciências Médicas de Porto Alegre (FFFCM PA) and Complexo Hospitalar Santa Casa de Porto Alegre (CHSCPA), Porto Alegre RS, Brasil: ${ }^{1}$ Neurologista do CHSCPA, M estre em Clínica Médica pela Universidade Federal do Rio Grande do Sul (UFRGS); 2Professora Titular de Anatomia Patológica da FFFCM PA, Livre-Docente em Anatomia Patológica pela FFFCM PA, Coordenadora do Programa de Pós-Graduação em Patologia da FFFCM PA; ${ }^{3}$ Neurologista do CHSCPA, Professora Adjunta de Anatomia Humana da FFFCM PA, Mestre e Doutora em Clínica Médica pela UFRGS.

Received 14 March 2003, received in final form 29 September 2003. Accepted 7 November 2003.

Dra. Arlete Hilbig - Rua Quintino Bocaiúva 283/401 - 90440-051 Porto Alegre RS - Brasil. E-mail: hilbiga@terra.com.br 
Glioblastoma is the most common malignant neoplasia of the central nervous system, with a prognosis of less than 24 months for most patients. Few prognostic factors have been identified in such tumors. Several biological markers are currently under research, in order to verify their predictive factors ${ }^{1,2}$. Apoptosis, or programmed cell death, plays an important role in cell proliferation control in physiological and pathological conditions. Such role has special interest for brain tumor development and progression. The deregulation of genetic pathways controlling apoptosis can favor growth and development of a tumor. Apoptosis is activated and regulated by a number of genes and proteins, such as $\mathrm{p} 53$, blc- 2 , and bax, among others. The apoptotic index (Al) is known to usually be higher in glioblastomas than in other astrocytic tumors, but its relationship with prognosis is still uncertain ${ }^{2-5}$.

P53, a cell proliferation regulating gene and a pro-apoptotic which is altered in as much as half of all astrocytomas, has a controversial role in glioblastoma prognosis $5^{6,7} . \mathrm{Bcl}-2$ and the blc-2 protein family are mostly considered anti-apoptotic, providing cells with a longer time of survival by preventing cell death. Bcl-2 expression in some tumors has been related to their own prognosis ${ }^{8}$. However, its prognostic correlation in glioblastomas is still controversia|3,9,10. The mitotic index (MI), assessed through M IB-1 (Ki-67), has proven useful in grading astrocytomas, though its predictive role in glioblastoma patient survival has not been confirmed ${ }^{4,11,12}$, as it exceeding ranges from 1 to $22 \%$.

In this study, it was intended to verify the importance of conducting immunohistochemical techniques on glioblastomas, noting if the presence of altered genes, such as p53 and blc-2, as well as apoptosis, can, in any way, contribute to a better understanding and, consequently, a better treatment for such neoplasia.

\section{METHOD}

\section{Sample}

Thirty patients above 18 years old with a diagnosis of glioblastoma between August 2000 and August 2001 were retrieved from the Department of Neuropathology of Fundação Faculdade Federal de Ciências M édicas de Porto Alegre files. They were all submitted to total surgical resection of the brain tumor at Complexo Hospitalar da Santa Casa de Porto Alegre (Hospital São José), Hospital de Beneficiência Portuguesa, and Hospital São Lucas da PUCRS. Neither patient presented a history of radiotherapy, chemotherapy, and/or previous tumor resection. Slides from all cases were reviewed to confirm histopathological diagnosis.

The time of survival was counted from day one - surgery - until 12 months after the surgical procedure had taken place. Death dates were known through death certificates supplied by the responsible state agency.

\section{Immunohistochemistry}

Thirty surgical specimens of formalin fixed and paraffin embedded tissue were studied. They were cut to $5 \mu \mathrm{m}$, deparaffined, and rehy- drated for the immunohistochemical technique, by using the Estreptoavidin-Biotin-Peroxidase method for visualizing the presence of $\mathrm{p53}$, blc-2 and Ki-67-M ib1. The material was placed in a microwave oven, in order to revert the effect of formaldehyde fixation, within a citrate buffer solution (pH 6.0) until boiling, when the temperature was reduced and kept moderately boiling for another $15 \mathrm{~min}$ utes, with stops for replenishing the lost liquid if necessary. The endogenous peroxidase activity was blocked with methanol containing $0.3 \% \mathrm{H}_{2} \mathrm{O}_{2}$ for 30 minutes. The tissue was rinsed with PBS and the material was then incubated with primary monoclonal antibodies and rested overnight in the fridge. Primary antibodies used were: for p53 (D07, DAKO), a 1:500-diluted mouse monoclonal antibody; for blc-2 (Clone 124, DAKO), also a mouse monoclonal antibody, diluted as 1:400, and for Ki-67-Mib1 (DAKO), a mouse monoclonal antibody diluted as 1:2000. After rinsing with PBS, cuts were incubated with a secondary mice antibody for 30 minutes at room temperature; and with the estreptoavidin-biotin-peroxidase complex for 30 minutes, undertaking a PBS rinsing between each step. The antigen-antibody complex was visualized with the cromogen DAB and counterstained with hematoxylin. As a positive control, previously positive breast cancer was used for p53 and KI-67/MIB-1 and lymph node for blc-2.

Apoptosis was determined through the TUNEL technique, using the Apoptag plus peroxidase in situ kit (S7101, Intergen). The material was incubated with $\mathrm{K}$ proteinase for 10 minutes at room temperature and after that, endogenous peroxidase was blocked with $\mathrm{H}_{2} \mathrm{O}_{2}$ for 5 minutes. The reagents in this kit are designated to mark the free DNA 3' $\mathrm{OH}$ terminal in situ with marked nucleotides. Nucleotides contained in the buffer reaction are enzymately connected to DNA by deoxynucleotidil transferase (TdT). Incubation with TdT is conducted at $37^{\circ}$ Celsius for 60 minutes and the enzyme catalyzes an addition of triphosphate nucleotides to the final $3^{\prime} \mathrm{OH}$ of the double or single helix DNA. Thereafter, incorporated nucleotides form an oligomer randomly by digoxigenin. After that, rinsing with buffer solution is conducted for 10 minutes and then the anti-digoxigenin antibody is applied and incubated in a damp environment for $30 \mathrm{~min}$ utes at room temperature. Detection of the antigen-antibody link is made through immunoperoxidase followed by $D A B$ cromogen. Castrated mice prostate was used as a positive control. The omission of TdT enzyme during the TUNEL technique was used as a negative control and resulted in the non-coloring of the plate.

For counting the tumor cells, 10 fields were chosen with highmagnification ( $x 500$ ), selecting the central tumor regions and avoiding necrosis areas, through the Sigma Scan Pro 5 imaging program. For calculating all the indexes, the following formula was used: number of stained cells/1000 total cells. Immunostained cells can be seen in slides showed in Figures 1 to 4.

Statistical analysis

Initially, quantitative data were described by using mean and standard deviation, and qualitative ones through absolute and percent frequencies. In asymmetry cases, median and interquartile amplitude (P25 and P75) were used. The survival estimate was described by using the Kapkan-M eier method. Feature comparison between both groups (dead and surviving patients) was conducted through chi-square (proportions), t-Student (symmetrical quantitative variables), and Mann-Whitney's U (asymmetrical quantitative variables) tests. For assessing the associations between immunohistochemical markers, 
survival time, and age, the Pearson's Correlation Coefficient was used. Due to the observed asymmetrical distributions, the logarithmic transformation was conducted for several variables. The adopted significance level was $\alpha=0.05$. Data were analyzed with the help of SPSS 10.0 (Statistical Package for the Social Sciences) and SigmaPlot 7.0 programs.

\section{RESULTS}

The demographic variables from the whole group are shown in Table 1. There was a predominance of males (70\%) and the patient average age was over 55. Significant differences between groups of dead and surviving patients were not detected (Table 2). The apoptosis index, as well as the other immunohistochemical markers, blc-2, M IB-1, and p53, in spite of presenting some oscillation between both groups, did not present statistically relevant differences (Table 2). The death curve (Fig 5) showed a relatively constant and regular death occurrence. After 12 months, it reached a survival-estimated probability of only $25 \%$. M ost correlation coefficients between vari-

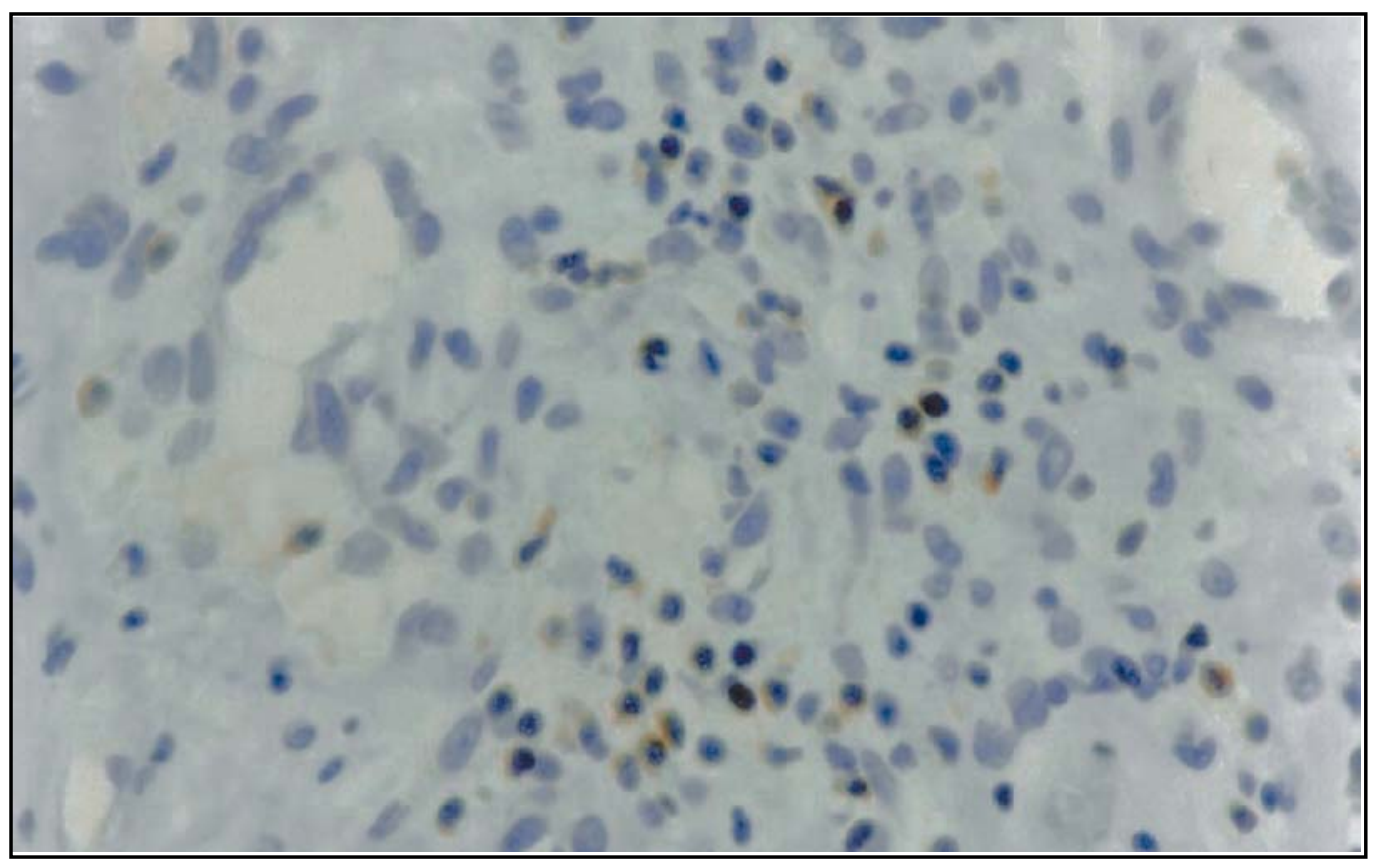

Fig 1. Glioblastoma with immunohistochemistry for BCL 2 (20 x).

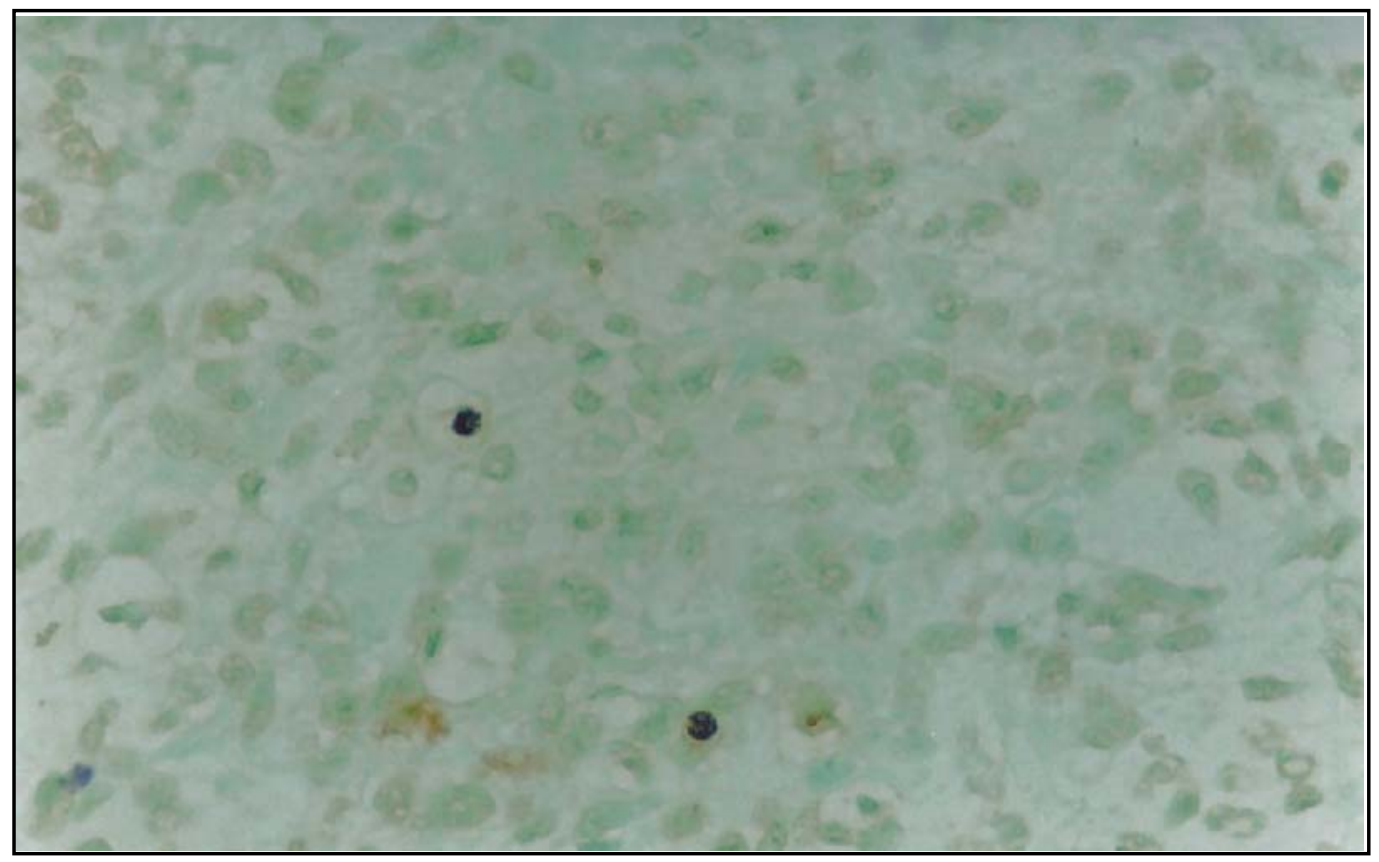

Fig 2. Glioblastoma with immunohistochemistry for apoptosis (tunel) 2 (20x). 


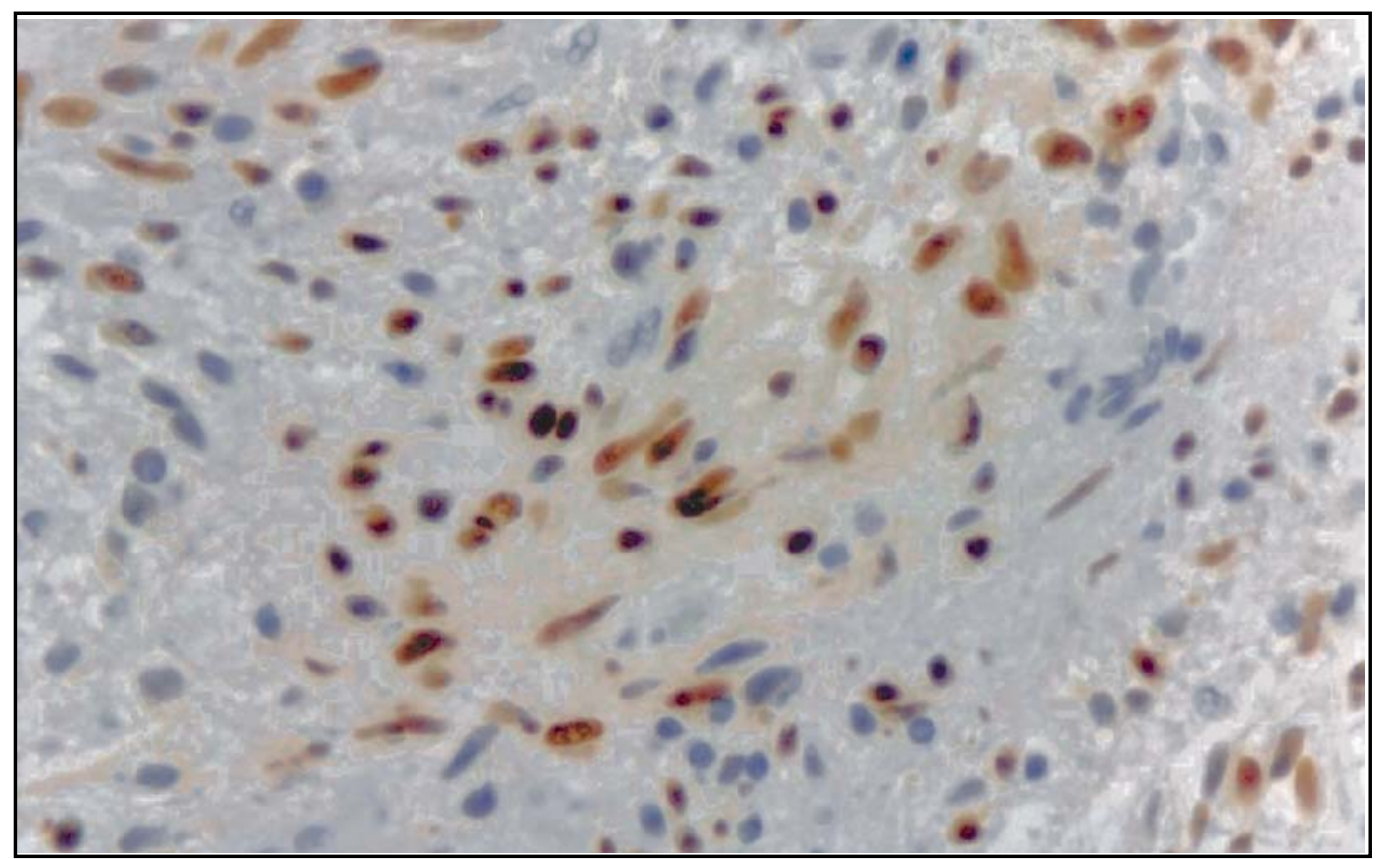

Fig 3. Glioblastoma with immunohistochemistry for p53 (20x).

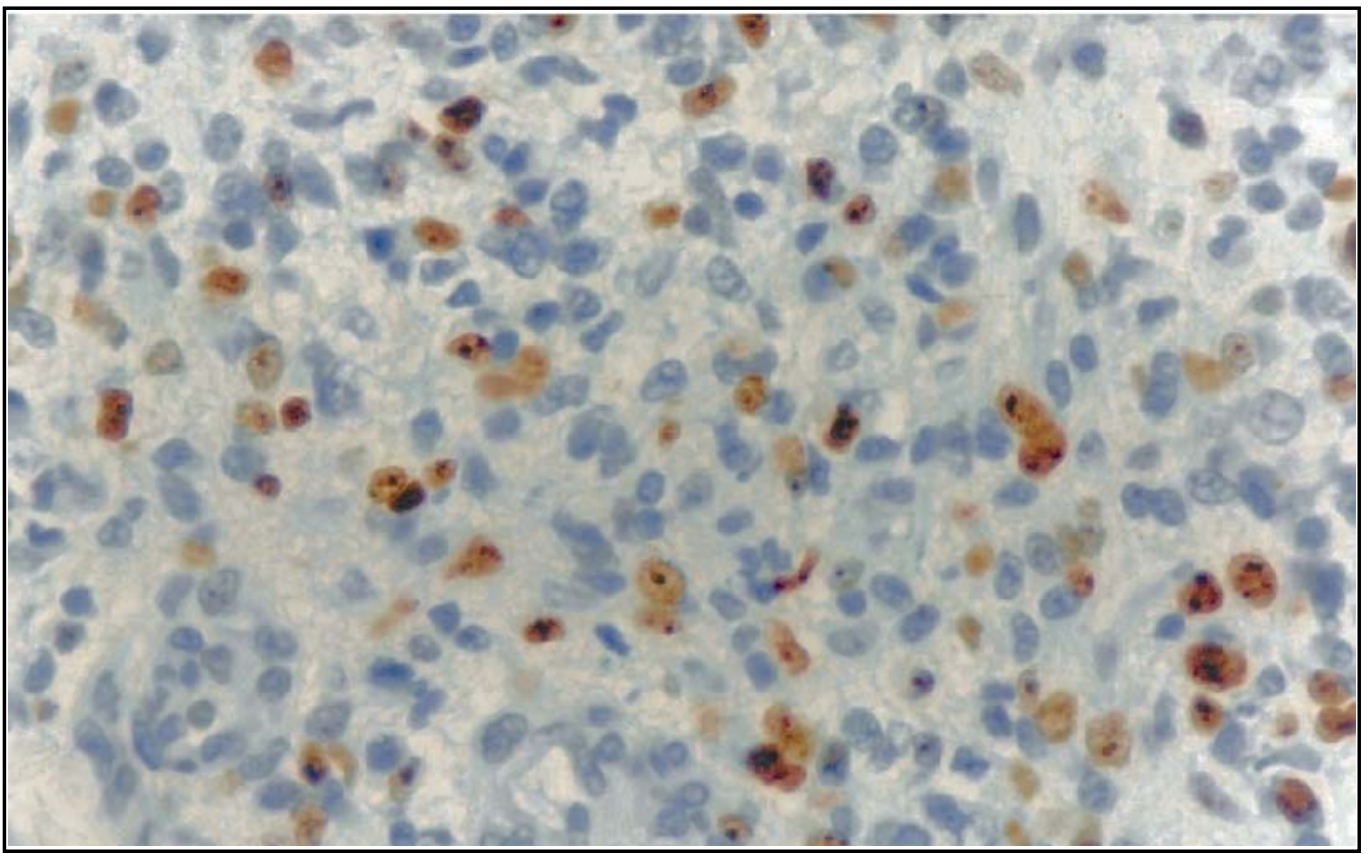

Fig 4. Glioblastoma with immunohistochemistry for M IB-1 (20 x).

ables (Figs 6,7, and 8) presented a trivial or very small association power, except for MIB-1, which presented a moderately reverse correlation with the apoptosis index and blc-2.

\section{DISCUSSION}

Glioblastomas are a group of neoplasias with a broad range of histological and biological findings and, in spite of that, present a homogeneous survival of approximately 1 year.
So far, the age at the time of diagnosis (bellow 45 years) is one of the few relevant criteria for patient prognosis ${ }^{13,14}$. In our study, no significant difference was found between patient age and survival time. We did note, however, a tendency of the dead patient group for presenting a higher age average than the survival group (59.5 and 51.9 years, respectively). Such difference would probably have statistical relevance if the sample were larger. A significant relationship between age and the 
Table 1. Demographic variables in patients diagnosed with glioblastoma $(n=30)$.

\begin{tabular}{cc}
\hline Variable & Value \\
\hline Male, $f(\%)$ & $21(70.0)$ \\
Age, years & $57.5 \pm 11.9$ \\
\hline
\end{tabular}

Data are presented as frequency (percentile) and mean \pm standard deviation

different expressions in immunohistochemical variables was not verified either, as already demonstrated in a previous study by New comb et al. ${ }^{1}$, who did not observe a relationship between glioblastioma patient survival and p53, blc-2, p16, EGFR, and MDM 2 expression, the last three not having been studied by us (Fig 7).

Apoptosis is an active form of cell death, requiring protein and macromolecule synthesis. It is associated with distinct morphological changes. Apoptosis is an important physiological process for maintaining tissue homeostasis and eliminating aberrant cell $s^{15,16}$. Some studies have demonstrated that the $\mathrm{Al}$ is higher in glioblastomas than in other astrocytic tumors. Ellison et al. ${ }^{3}$ observed that the Al increased with an increase in astrocytic tumor anaplasia in 81 cases, of which 16 were fibrillary astrocytomas, 19 were anaplasic astrocytomas, and 46 were glioblastomas. Carrol et al. ${ }^{16}$ studied a total of 59 cases of astrocytic neoplasias and the presence of apoptosis in those tumors. They concluded that low-graded astrocytomas possessed a lower AI than anaplasic ones and glioblastomas. Heesters et al. ${ }^{4}$ also observed a higher Al in glioblastomas than in anaplasic astrocytomas, and did not find a prognostic role of $A I$ in those patients' survival. Tew $S^{17}$, studying 46 gliomas, found a higher $\mathrm{Al}$ in glioblastomas than in other astrocytic tumors, and, like Heesters and collaborators ${ }^{4}$, did not find a relationship between $\mathrm{Al}$ and time of survival. How ever, Shiffer et al. ${ }^{10}$, studying 180 human neuroepithelial tumors, found a lower $\mathrm{Al}$ in glioblastomas than in other gliomas but as others ${ }^{4,17}$, could not demonstrate a prognostic role of apoptosis in such tumors. Yet, Korshunov et al. ${ }^{2}$ found a significant direct relationship between $\mathrm{Al}$ and survival in 168 cases of glioblastomas. Our results have not demonstrated a significant correlation between apoptosis and survival time (Fig 6).

The regulation of apoptosis takes place through a number of mechanisms. As a part of such a complex control, the p53 protein is considered pro-apoptotic. However, its mutation, verified in neoplasic processes, can nullify its cell-growthregulating condition ${ }^{18}$. Loss or mutation in the p53 gene has been detected in many gliomas and represent an early event in the origin of astrocytomas ${ }^{19}$. Cunningham et al. ${ }^{6}$ analyzed 120 glial tumors and observed p53 positivity in $85 \%$ of the cases, but have not found a relationship betw een the presence

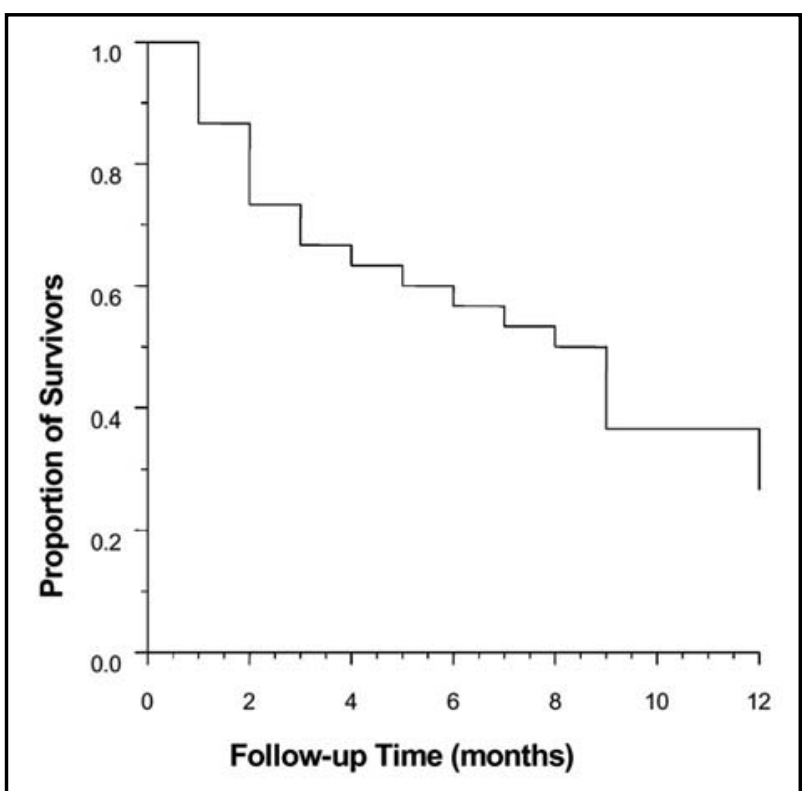

Fig 5. Kaplan-M eier's curve, representing survival time for 30 patients diagnosed with glioblastoma.

Table 2. Comparison of demographic and imunohistochemical variables between dead and surviving patients diagnosed with glioblastoma.

\begin{tabular}{lccc}
\hline Variable & $\begin{array}{c}\text { Dead } \\
n=22\end{array}$ & $\begin{array}{c}\text { Survivors } \\
n=8\end{array}$ & $P$ \\
\hline Male, $f(\%)$ & $15(68.2)$ & $6(75.0)$ & 0.999 \\
Age, yaers & $59.5 \pm 12.3$ & $51.9 \pm 9.0$ & 0.122 \\
Apoptosis, \% & $7.5(4.2 \mathrm{a} 36.0)$ & $5.0(2.5 \mathrm{a} 26.4)$ & 0.344 \\
Bcl-2 & $0.0(0.0 \mathrm{a} 11.8)$ & $3.0(0.0 \mathrm{a} 13.9)$ & 0.662 \\
P53 & $0.0(0.0 \mathrm{a} 25.2)$ & $2.2(0.0 \mathrm{a} 49.6)$ & 0.629 \\
MIB-1 & $20.5(13.9$ a 28.7$)$ & 29.7 (15.6 a 33.4) & 0.202 \\
\hline Data are presented as frequency (percentile) and median and interquartile amplitude (P25 to P75)
\end{tabular}




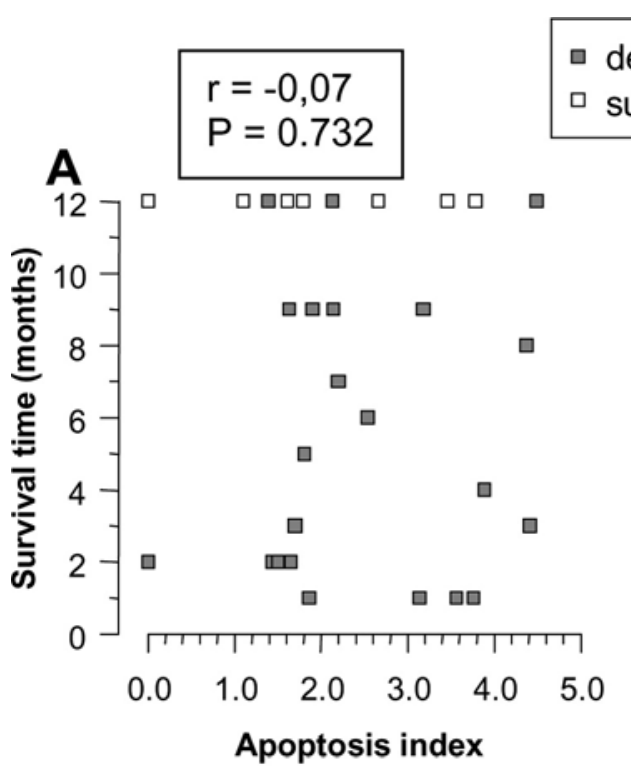

dead

survivors
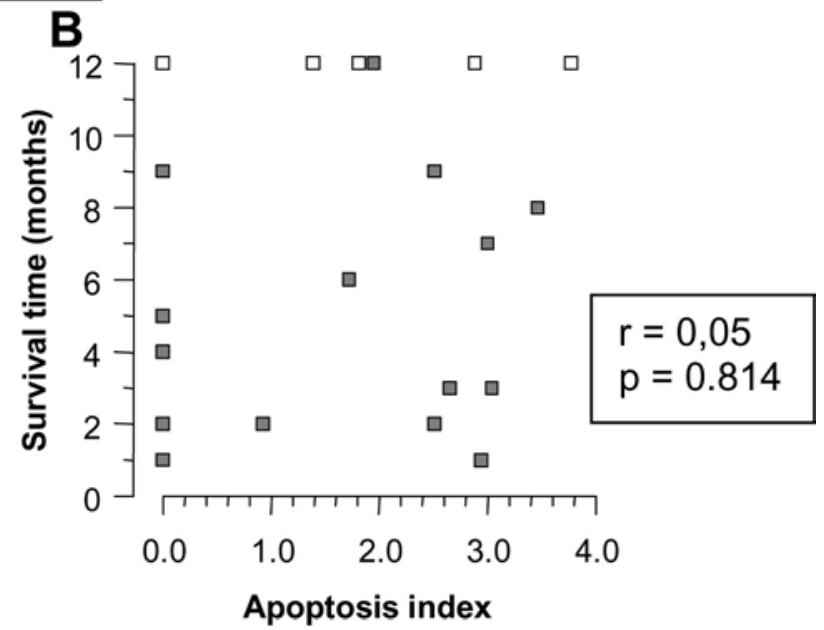

C

D

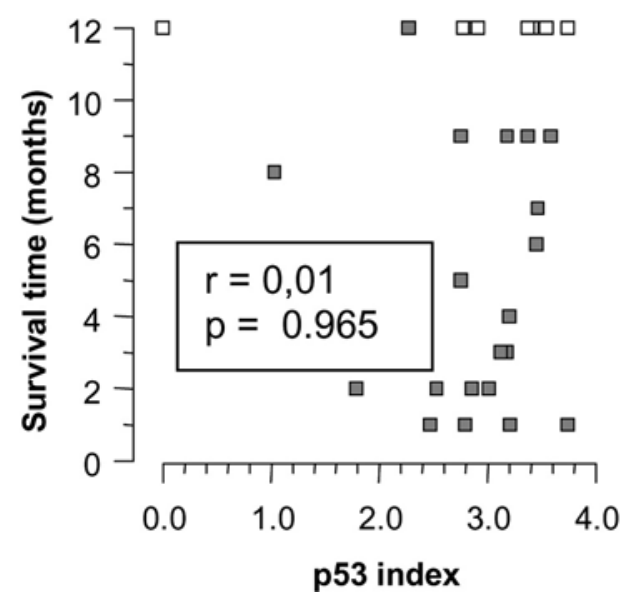

Fig 6. Scatterplots representing correlations foud between time of survival and immunohistochemical variables.

of p53 and survival time. Kraus et al. ${ }^{20}$ have also not demonstrated a relationship between the presence of $p 53$ in primary glioblastomas and the prognosis of the patients. Jaros et al..$^{21}$ and Van Meyel et al..$^{22}$ have demonstrated a significant relationship of the mutation of p53 gene and the accumulation of its protein to a worse prognosis in gliomas. We verified that there was no association between the presence of p53 and patients' survival time (Fig 6), as well as a relationship betw een p53 and the patients' age (Fig 7), though the association between p53 and an age lower than 45 is known in so-called secondary glioblastomas ${ }^{23}$. A greater number of studies need to be conducted in order to clarify the age-stratified role of p53 gene alterations in glioblastomas, as it is known that the presence of $\mathrm{p} 53$ is greater in secondary glioblastomas, which are found in younger, and therefore, better-prognosis patients.
It has been suggested that the MI of gliomas can have a predictive value in their own prognosis ${ }^{6,24}$. Ehrmann et al. ${ }^{25}$ demonstrated a relationship between cell proliferation (as measured by the PCNA protein expression) and the prognosis of 42 astrocytic tumors. In the study by Cunningham et al. ${ }^{6}$, there was a prognostic relationship with MIB-1 and PCNA values, which disappeared after an adjustment was made for age and gradation of the 120 astrocytic tumors.

Other studies have demonstrated that, is spite of an increase in cell proliferation along with the increase in the malignity degree of the astrocytomas, the prognostic value of $\mathrm{MI}$ is not clearly demonstrated in glioblastomas ${ }^{4,10,26}$. It has been observed that there was no relationship between the indexes of cell proliferation and the time of survival, confirming findings 


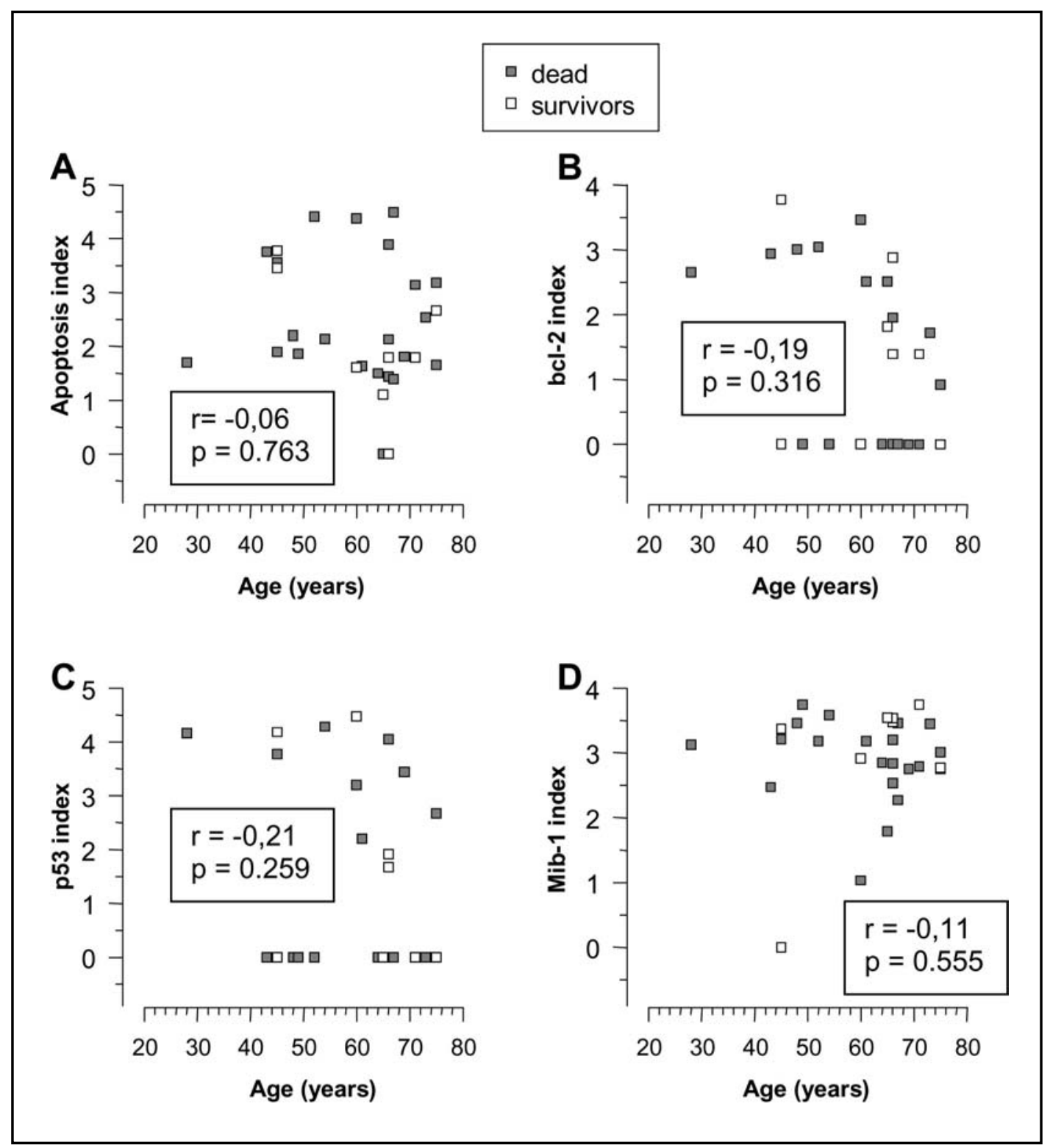

Fig 7. Scatterplots representing correlations found between age and immunohistochemical variables.

from previously mentioned studies. There was, however, a moderate reverse correlation $(p=0.058)$ between $\mathrm{MI}$ and AI, as also demonstrated by Heesters ${ }^{4}$ (Fig 8).

Blc-2, a gene established as programmed cell death suppressor, is not found in normal astrocytes within the cortex, white matter or cerebellum. However, it is found in more than half of all astrocytomas in adults, as demonstrated by Ellison et al. ${ }^{3}$, who found the presence of blc- 2 in $44 \%$ of the fibrillary astrocytomas, $42 \%$ of the anaplastic astrocytomas, and $28 \%$ of the glioblastomas; by Rieger et al. ${ }^{27}$, who found a $70 \%$ blc-2 positivity in 20 glioblastomas; and by New comb et al. ${ }^{1}$, who observed $57 \%$ of positivity for blc- 2 in astrocytomas in 37 adult patients and in $73 \%$ of 21 pediatric cases. The prognostic role of the blc-2 expression remains uncertain. We could not demonstrate a significant relationship between indexes of blc- 2 and survival, as had already been observed by Nakasu et al. ${ }^{9}$, New comb et al. ${ }^{8}$ and New comb et al. ${ }^{1}$ (Fig 6). We did verify, however, a statistically significant reverse correlation $(p=0.034$ ) between the blc- 2 index and the cell proliferation index (Fig 8). Such finding can indicate a greater role for bax, a member of the blc-2 family with a pro-apoptotic function, in this group of tumors. However, further studies are needed for clarifying such finding.

Our study had limitations regarding the verification of important prognostic factors in glioblastomas, such as the quantification of the dried up tumor mass by the pre- and postoperatory imaging examinations, the clinical condition of the patient at the pre- and post-surgical time through clinical and neurological examination, and the time of evolution of the disease until diagnosis, which is one of the criteria for classify- 


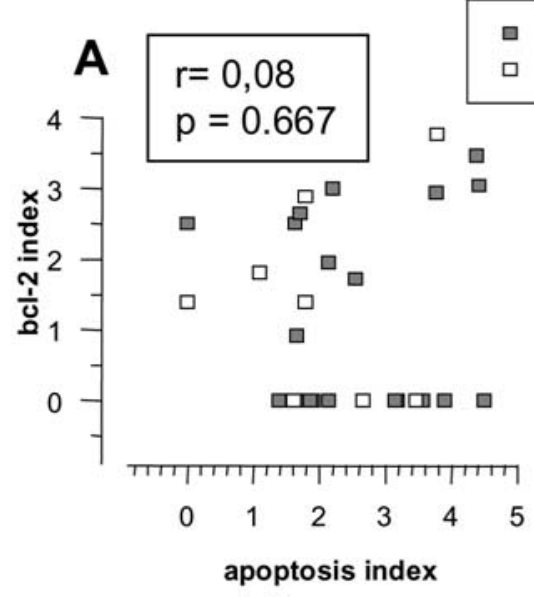

B

survivors
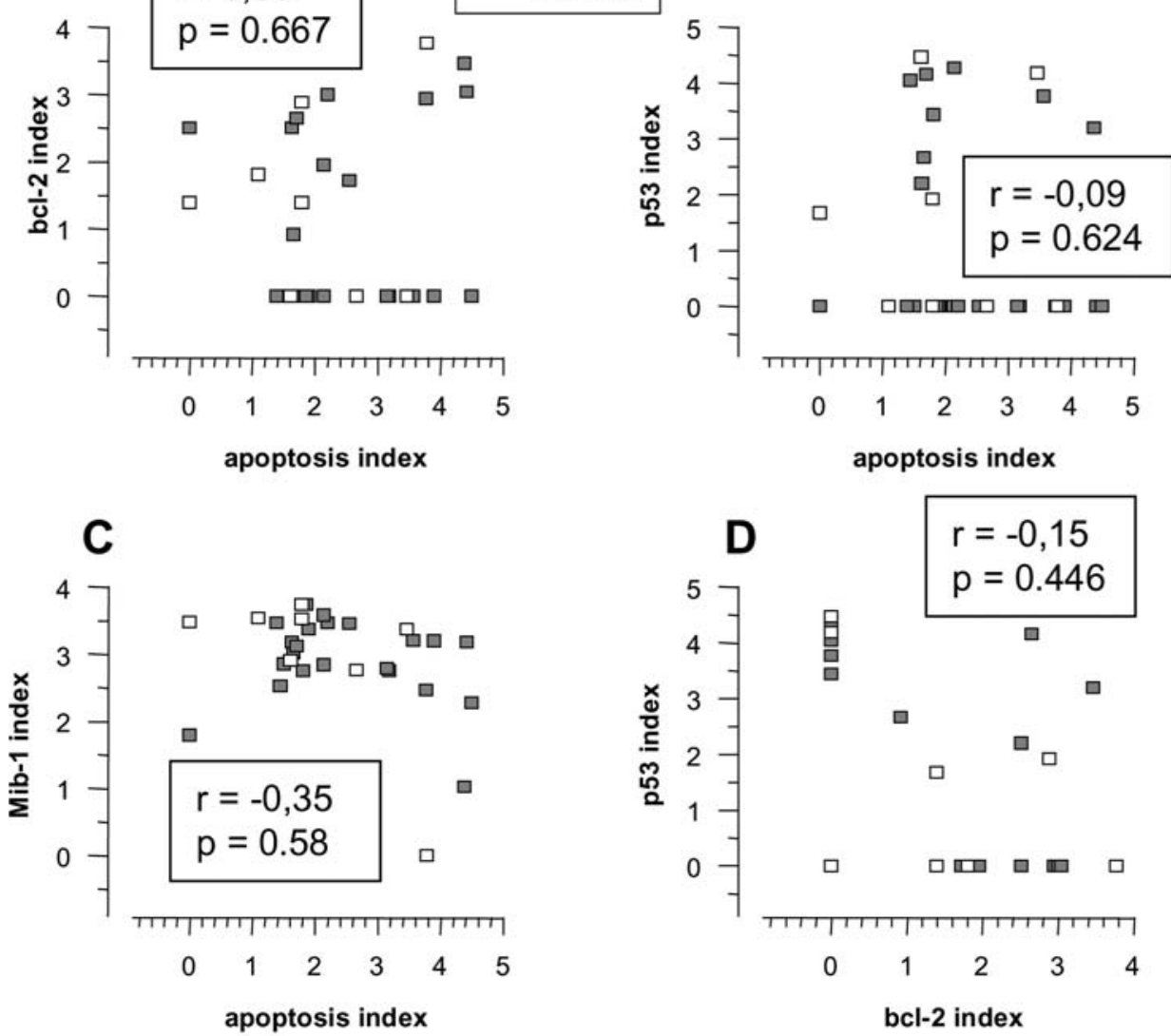

E

$\mathbf{F}$
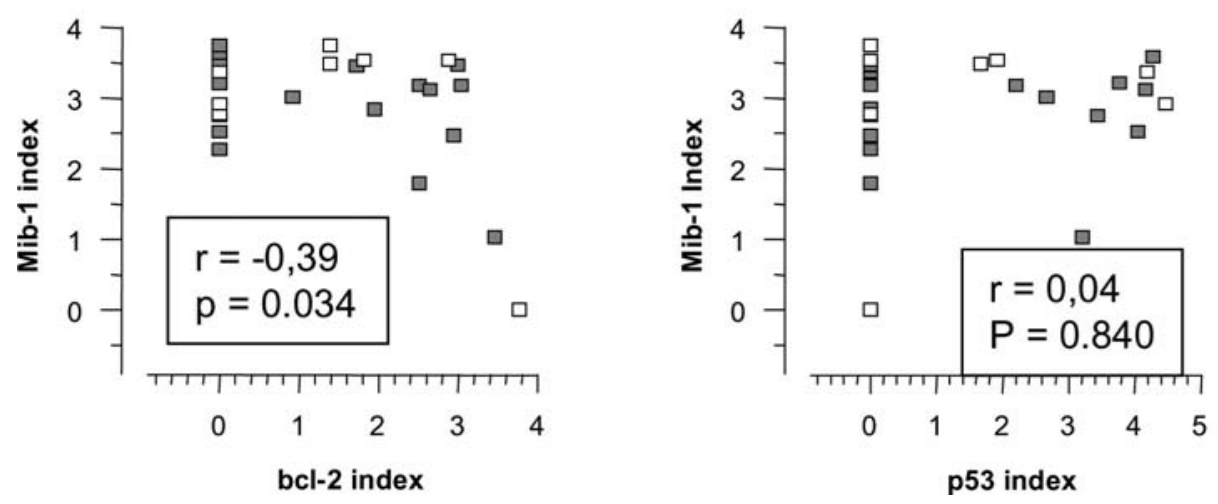

Fig 8. Scatterplots representing correlations found between immunohistochemical variables.

ing between primary and secondary glioblastomas.

\section{CONCLUSION}

The reverse correlation between $\mathrm{Al}$ and $\mathrm{MI}$ can be seen in our study, suggesting that the presence of apoptosis can prevent tumor growth, though a significant relationship between the presence of apoptosis and time of survival was not demonstrated. A reverse relationship between the blc- 2 index and
$\mathrm{MI}$ is also seen. Similar data could not be found in the literature. Thus, further studies need to be conducted to confirm such finding. In our study, none of the examined factors was relevant for patient prognosis, but as already discussed, there was a tendency in the patient group with age bellow 45 for having a longer time of survival. M oreover, we can conclude that the apoptosis phenomenon in glioblastomas depends upon highly complex genetic pathways, independently from p53 and 


\section{blc-2, since no relationship was established between such genes and the presence of apoptosis.}

\section{REFERENCES}

1. Newcomb EW, Cohen H, Lee SR, et al. Survival of patients with glioblastoma is not influenced by altered expression of p16, p53, EGFR, MDM2 or bcl-2 genes. Brain Pathol 1998;8:655-667.

2. Korshunov A, Golanov A, Sycheva R, Pronin I. Prognostic value of tumor associated antigen immunoreactivity and apoptosis in cerebral glioblastomas: an analysis of 168 cases. J Clin Pathol 1999;52:574-580.

3. Ellison DW, Steart PV, Gatter KC, Weller RO. Apoptosis in cerebral astrocytic rumours and its relationship to expression of bcl-2 and p53 proteins. Neuropathol Applied Neurobiol 1995;21:352-361.

4. Heesters MA, Koudstaal J, Go KG, Molenaar WM. Analysis of proliferation and apoptosis in brain gliomas: prognostic and clinical value. J Neuro Oncol 1999;44:255-266.

5. Schiffer D, Cavalla A, Migheli A, et al. Apoptosis and cell proliferation in human neuroepithelial tumor. Neurosc Letters 1995;195:81-84.

6. Cunninghan JM, Kimmel DW, Schethauer BW, et al. Analysis of proliferation markers and 553 expression in gliomas of astrocytic origin: relationships and prognostic value. J Neurosurg 1997;86:121-130.

7. Sipos L, Szegedi Z, Fedorscsak I, Afra D, Szende B. Apoptosis and p53 in human giomas. Pathol Oncol Res 1998;4:267-270.

8. Newcomb EW, Bhalla SK, Parrish CL, Hayes RL, Cohen H, Miller DC. bcl-2 protein expression in astrocytomas in relation to patient survival and p53 gene status. Acta Neuropathol 1997;94:369-375.

9. Nakasu S, Nakasu Y, Nioka H. bcl-2 protein expression in tumors of central nervous system. Acta Neuropathol 1994;88:520-526.

10. Schiffer D, Dutto A, Cavala P, et al. Prognostic factor in oligodendroglioma. Can J Neurol Sci 1997;24:313-317.

11. Ang LD, Plewes M, Tan L, Begley H, Agranovich A, Shul D. Proliferating cell nuclear antigen expression in the survival of astrocytoma patients. Can J Neurol Sci 1994;21:306-310.

12. Coons SW, Jonhson PC, Pearl DK. Improving interobserver correlation in the classification and gradind of astrocytomas. J Neuropathol Exp Neurol 1993;52:288.

13. Burger PC, Green SB. Patient age, histological features and length of survival in patients with glioblastoma multiforme. Cancer 1987;59:1617-1625.

14. Salmon I, Dewitte O, Pasteels JL, et al. Prognostic scoring in adult astrocytic tumors using patient age, histopathological grade and DNA histogram type. J Neurosurg 1994;80:877-883.

15. Reed JC, Meister L, Tanaka S, et al. Differential expression of bcl-2 protooncogene in neuroblastomas and others tumor cells lines of neural origin. Cancer Res 1991;51:6529-6538.

16. Carrol RS, Zhang J, Chauncey BW, et al. Apoptosis in astrocytic neoplasms. Acta Neurochir (Wien) 1997;139:845-850.

17. Tews DS. Cell death and oxidative stress in gliomas. Neuropathol Applied Neurobiol 1999;25:272-284.

18. Symonds H, Drall L, Remington L, et al. p53 dependent apoptosis suppresses tumor growth and progression in vivo. Cell 1994;78:703-711.

19. Van Meir EG, Kikuchi T, Tada M, et al. Analysis of the p53 gene and its expression in human glioblastomas cell. Cancer Res 1004;54:649-652.

20. Kraus JA, Wengoefer M, Glesmann N. TP53 gene mutations, nuclear p53 accumulation, expression of Waf/p21, bcl-2 and CD95 proteins are not prognostic factors in de novo glioblastoma. J Neurooncol 2001;52:263-272.

21. Jaros E, Perry RH, Adam L, et al. Prognostic implications of p53 protein, epidermal growth factor receptor and ki-67 labelling in brain tumors. Cancer 1992;66:373-385.

22. Van Meyel DJ, Ramsay DA, Casson AG, Keenez M, Chamberg AF, Caincross JG. Pattern of mutant p53 expression and DNA ploidy in evolving gliomas. J Natl Cancer Inst 1994;86:1011-1017.

23. Kleihues P, Ohgaki H. Primary and secondary glioblastoma: from concept to clinical diagnosis. Neuro Oncol 1999;1:44-51.

24. Kirkegaard LJ, DeRose PB, Yao B, Cohen C. Image cytometric measurement of nuclear proliferation markers (MIB-1, PCNA) in astrocytomas. Prognostic significance. Am J Clin Pathol 1998;109:69-74

25. Erhmann J Jr, Kolar Z, Vojtesek B, Kala M, Komenta S. Prognostic factors in astrocytomas: relationship of p53, MDM-2, bcl-2 and PCNA immunohistochemical expression to tumor grade and overall patient survival. Neoplasma 1997;44:299-304.

26. Hsu DW, Louis DN, Efird JT, Hedley ET. Use of MIB-1 (Ki-67) immunoreactivity in diferentiating grade II and grade III gliomas. J Neuropathol Exp Neurobiol 1997;56:857-865.

27. Rieger L, Weller M, Bornemann A. bcl-2 family protein expression in human malignant glioma: a clinical pathological correlative study. J Neurol Sci 1998;155:68-75. 